\title{
TRAINING NEEDS OF THE FISH FARMERS ON INTEGRATED FISH FARMING
}

\author{
M. S. Yeasmin, M. J. Hoque and M. Z. Rahman \\ Department of Agricultural Extension Education, Bangladesh Agricultural University \\ Mymensingh-2202, Bangladesh
}

\begin{abstract}
The study was carried out to determine the extent of training needs of the fish farmers on integrated fish farming and to explore the relationship between the selected characteristics of the fish farmers and their extent of training needs on integrated fish farming (IFF). Four villages, namely North Gouari, South Gouari, Rajpur and Satrasia under Muktagacha Upazila (sub-district) of Mymensingh district were the locale of the study. Ninety fish farmers (out of the total of 300) were randomly selected as a sample of the study. Data were collected from the sample of fish farmers by using a pre-tested interview schedule through personal interview method during 15 to 30 April 2013. Pearson's Product Moment Correlation Coefficient ( $\mathrm{r}$ ) was computed to explore the relationships between the selected characteristics of the respondents and their extent of training needs on IFF. Training needs of the fish farmers on IFF was the dependent variable and selected characteristics of the respondents constituted the independent variables of the study. The highest proportion (56.7 per cent) of the respondents had high training needs while 42.2 per cent of the respondents had medium and only 1.1 per cent had low training need on IFF. The 'training needs for selection of diseases free seed and species' ranked first followed by 'training needs for ways of diseases control'. Sequentially 'training needs for breed selection' was third, 'training needs for stocking density of fish species' was fourth 'training needs for preventive measures of diseases' was fifth and 'training need for techniques of egg collection' was last in the rank order. Correlation analyses indicated that five characteristics of the integrated fish farmers, namely years of schooling, organizational participation, communication exposure, social mobility and knowledge with IFF had significant positive relationships with their extent of training needs on IFF. The household size, age and annual income showed no significant relationships with their extent of training needs on IFF and showed negative trend. The main problems on IFF were unavailability of quality seed and species, lack of financial support, lack of knowledge on species selection, lack of marketing facilities, lack of knowledge on fish processing and preservation. The extension service providers should arrange more training and motivational campaign for the fish farmers on IFF.
\end{abstract}

Key Works: Training, Need, Integrated, Fish farmer, Farming

\section{INTRODUCTION}

The people of Bangladesh are commonly referred to as 'Macche-Bhate Bangali' (i.e., the people made of fish and rice). Fish is renewable natural resource and plays a great role for the improvement of socio-economic condition of poor fishers. Fisheries sector contributes $58 \%$ of an animal protein to our daily diet (DoF, 2011). The demand of fish has increased 
due to increase in population. Annual total fish demand is 2.45 million MT and per capita fish requirement is $18.00 \mathrm{~kg}$ per year. But the current consumption is $16.69 \mathrm{~kg}$ this has got a negative impact on the health condition of the people (Kausar, 2009). The situation can not be allowed to continue for long years. For that, Bangladesh had to overcome these problems very urgently. By introducing mixed culture system and integrated aquaculture system, the fish production can be increased to many folds. Fish production in ponds, floodplains, oxbow lakes and semi-enclosed water bodies are increasing day by day through the transfer of modern technologies. Integrated fish farming is a technique of fish culture with other organisms (animal/s or plant/s). Major objective of this technique is to get maximum output through involving minimum input supply in minimum time duration. Fish culture can be integrated with several systems for efficient resource utilization. The pond-dike system, where fish are raised in ponds and a crop are grown on the dikes or in the immediate vicinity of the pond, is well known for its ability to maximize energy input and minimize wasted energy output through the recycling of organic wastes among components of the system (Ruddle and Zhong, 1988 and Pearce, 2006). The system integrates agriculture, livestock and aquaculture, three separate component of farming systems into one physically linked ecosystem (Lo, 1996). Integration of aquaculture with rice farming improves sustainability, productivity and profitability of the farm (Lightfoot et. al., 1990). This farming system is to produce an estimated 400,000 tones fish a year worth US\$ 300 million on 40,000 hectares of land, says World Fish Centre. Duck-cum-fish integrated farming system has been introduced by Bangladesh Fisheries Research Institute in 1986. After several trials it has been found that the average fish yield of 5.68 tons/ha/year from duck-fish experiment. This yield was 5-7 times higher than the normal fish production (Nuruzzaman, 1991).

Livestock-fish integration had received considerable attention in the past, though most livestock-fish integrated systems promotional programs failed to take into account the existing farming systems. For example, feedlot livestock-fish, poultry fish, or pig-fish integration are often promoted uncritically as a means to improve the welfare of small-scale resource poor farms in Asia (Wahab et al., 1997; Little and Edwards, 2003). Such systems virtually rely on costly formulated feed, and therefore, rarely succeed on small-scale resource-poor farms (AIT, 1994; Edwards et al., 1996; Little and Edwards, 1999; Little and Edwards, 2003). The scope of integrated fish farming is considerably wide. IFF complements and improves the overall yield in term of laborer input and efficiency as well as resources uses (Little and Muir, 2003). The basic principles involved in integrated farming are utilization of the synergetic effects of integrated farming activities and the conservation including the full utilization of farm waste. It is based on the concept that "there is no waste" and waste is only a misplaced resources which can become a valuable material for another product (FAO, 1977).

But due to lack of adequate knowledge and skills of the fish farmers towards integrated fish farming they are not able to maximize their productivity. Because fisheries technology is continuously changing, many skills are needed for use of these techniques by the fish farmers in increasing production. For this reason it is necessary to arrange timely training programmers to acquire necessary knowledge and skills in different aspects of improved 
integrated fish farming. A well trained integrated fish farmers able to ensure more fish production. Meenambigai and Seetharaman (2003) asserted that training is the most singular factor affecting individuals' attitude, productivity, improvement, minimization of risks. So, adequate training is essential for the integrated fish farmers on integrated fish farming. Based on the above issues the study was carried out to determine the extent of training needs of the fish farmers on integrated fish farming and to explore the relationship between the selected characteristics of the fish farmers and their extent of training needs on integrated fish farming.

\section{METHODOLOGY}

The study was conducted in Muktagacha Upazila (sub-district) under Mymensingh district, Bangladesh. Among 10 unions two unions namely Basati and Kumarghata were selected purposively as a study location. Basati union has 12 villages and Kumargata union has 11 villages. Out of these villages, South Gouari, North Gouari, Rajpur and Satrasia villages were selected purposively as integrated fish farming of these areas was higher than other villages. The selection was made on the basis of suggestions made by Upazila Fisheries Officer (UFO) and other relevant officials of Muktagacha Upazila. Total number of fish farmers in the selected four villages was 300 which constituted the sampling population. A list of all these (300) fish farmers was prepared to make it a sample frame. In the second step $30 \%$ of the fish farmers of each of the four villages were selected as sample by using a table of random numbers. Ninety (90) fish farmers were selected in this way and constituted the sample for this study. In order to collect relevant data, a structured interview schedule was carefully prepared keeping the objectives of the study in mind. No serious difficulty was faced by the researcher in collecting data. The survey was conducted in 15 April to 30 April 2013. Descriptive statistics such as range, number, and mean, per centages, rank order and standard deviation were used for describing the variables of the study. Pearson's Product Moment Correlation Co-efficient was used to explore the relationships between any two concerned variables.

\section{Measurement of the extent of training needs of the fish farmers}

Training needs of the fish farmers on integrated fish farming was the dependent variable of the study. To measure the training needs of the fish farmer on integrated fish farming six dimensions of integrated fish farming were considered such as preparation of pond, selection of quality seed, species and their stocking density, water quality management, feed and fertilizer management, insects and diseases control, and harvesting, fish preservation and marketing of the products. The selected dimensions were measured on a four-point rating scale. Scores were assigned as 3, 2, 1 and 0 for 'high', 'medium', 'low', and 'no' training needs, respectively. The scores of all items (total 29) of each dimension were added to obtain the total score of a single dimension. Finally, scores of all the six dimensions formed the total score of the training needs on integrated fish farming of fish farmer for each respondent. Thus, total score of each respondent for this variable could range from 0 to 87 , where 0 indicated 'no training needs' and 87 indicated 'high training needs' of the fish 
farmer on integrated fish farming. The training needs index on integrated fish farming was also measured mathematically and expressed in the following ways:

Training needs index on IFF $=($ Actual training needs $/$ Possible training needs $) \times 100$

\section{FINDINGS AND DISCUSSION}

\section{Overall training needs of the fish farmers}

The total score of training needs could range from 0 to 87 . However, the observed training needs scores ranged from 29 to 86 with an average of 62.39 and standard deviation of 14.03. Based on their training needs scores the respondents were classified into three categories as shown in Table 1.

Table 1. Distribution of fish farmers according to their overall scores of training needs

\begin{tabular}{|c|c|c|c|c|c|}
\hline \multicolumn{2}{|c|}{ Score } & \multicolumn{2}{|c|}{ Respondents } & \multirow[t]{2}{*}{ Mean } & \multirow[t]{2}{*}{$\mathrm{SD}$} \\
\hline Possible & Observed & Categories & Respondents per cent $(n=90)$ & & \\
\hline \multirow[t]{3}{*}{0 to 87} & 29 to 86 & Low needs (up to 29) & 1.1 & 62.39 & 14.03 \\
\hline & & Medium needs (30 to 60 ) & 42.2 & & \\
\hline & & High needs $(>60)$ & 56.7 & & \\
\hline
\end{tabular}

Data presented in the Table 1 shows that the highest proportion (56.7 per cent) of the respondents had high extent of training needs while 42.2 per cent of them had medium and only 1.1 per cent had low extent of training needs on integrated fish farming. The findings clearly indicate that more than half (56.7 per cent) of the respondents had high training needs on integrated fish farming. The fish farmers in the study area kept desire for integrated fish farming but they could not perform due to lack of knowledge and sufficient information about the expected activities. Thus, the respondents logically felt high training needs on integrated fish farming. Similar results were found by Ferdousi (2010) and Ahmed (2007).

\section{Item-wise training needs of the fish farmers on IFF}

To measure the extent of training needs of fish farmers on integrated fish farming there were 29 items under six dimensions of integrated fish farming. From Table 2, it was cleared that fish farmers had first priority to get training on 'selection of diseases free seed and second and third priority were 'ways of diseases control' and 'breed selection'. The fourth priority was for 'stocking density of fish species' and fifth was 'preventive measures of diseases'. Thus, it was clear that fish farmers had a lack of skills on fish disease management. 
Table 2. Extent of training needs of the integrated fish farmers on IFF $(n=90)$

\begin{tabular}{|c|c|c|c|c|c|c|c|c|}
\hline \multirow[t]{2}{*}{$\begin{array}{l}\text { Sl. } \\
\text { No. }\end{array}$} & \multirow[t]{2}{*}{ Items } & \multicolumn{4}{|c|}{$\begin{array}{c}\text { Extent of training } \\
\text { needs } \\
\text { (no. of fish farmers) }\end{array}$} & \multirow[t]{2}{*}{ TS } & \multirow[t]{2}{*}{ M } & \multirow[t]{2}{*}{$\mathrm{P}$} \\
\hline & & $\mathrm{H}$ & $\mathrm{M}$ & $\mathrm{L}$ & $\mathrm{N}$ & & & \\
\hline \multicolumn{9}{|c|}{ A. Preparation of pond } \\
\hline 1. & Weed management in pond & 22 & 21 & 16 & 31 & 124 & 1.38 & 26 \\
\hline 2. & Lime and fertilizer management in a pond & 26 & 29 & 16 & 19 & 152 & 1.69 & 24 \\
\hline 3. & Systems of water depth measurement & 36 & 30 & 13 & 11 & 181 & 2.01 & 15 \\
\hline 4. & $\begin{array}{l}\text { Techniques for checking phytoplankton and } \\
\text { zooplankton }\end{array}$ & 51 & 22 & 12 & 5 & 209 & 2.32 & 10 \\
\hline 5. & Use of pond-dike for vegetable cultivation & 44 & 24 & 16 & 6 & 196 & 2.18 & 12 \\
\hline 6. & Irrigation and drainage management & 34 & 25 & 18 & 13 & 170 & 1.89 & 18 \\
\hline 7. & Preparation of livestock shed & 41 & 13 & 11 & 25 & 160 & 1.78 & 22 \\
\hline \multicolumn{9}{|c|}{ B. Selection of quality seed, species and their stocking density } \\
\hline 8. & Selection of components for IFF & 68 & 12 & 3 & 7 & 231 & 2.57 & 8 \\
\hline 9. & Selection of diseases free seed and species & 77 & 12 & 1 & 0 & 256 & 2.84 & 1 \\
\hline 10. & Identification of fish species suitable for IFF & 57 & 29 & 3 & 1 & 232 & 2.58 & 7 \\
\hline 11. & Stocking density of fish species & 69 & 15 & 4 & 2 & 241 & 2.68 & 4 \\
\hline 12. & $\begin{array}{l}\text { Selection of quality seed and seedling of } \\
\text { vegetable }\end{array}$ & 61 & 22 & 5 & 2 & 232 & 2.58 & 7 \\
\hline 13. & Breed selection & 75 & 9 & 5 & 1 & 248 & 2.76 & 3 \\
\hline \multicolumn{9}{|c|}{ C. Water quality management } \\
\hline 14. & $\mathrm{pH}$ and Oxygen level measurement & 44 & 20 & 14 & 12 & 186 & 2.07 & 14 \\
\hline 15. & $\begin{array}{l}\text { Measurement of optimum level of water } \\
\text { temperature }\end{array}$ & 36 & 21 & 15 & 18 & 165 & 1.83 & 20 \\
\hline 16. & Ways of water exchange & 20 & 23 & 24 & 23 & 130 & 1.44 & 25 \\
\hline \multicolumn{9}{|c|}{ D. Feed and fertilizer management } \\
\hline 17. & Way of feed application & 33 & 25 & 22 & 10 & 171 & 1.90 & 17 \\
\hline 18. & Proper time of feed application & 30 & 27 & 23 & 10 & 167 & 1.86 & 19 \\
\hline 19. & Doses of fertilizer application & 36 & 27 & 17 & 10 & 179 & 1.99 & 16 \\
\hline \multicolumn{9}{|c|}{ E. Insects and diseases control } \\
\hline 20. & Identification of diseases & 64 & 15 & 9 & 2 & 231 & 2.57 & 8 \\
\hline 21. & Preventive measures of diseases & 64 & 22 & 4 & 0 & 240 & 2.67 & 5 \\
\hline 22. & Ways of diseases control & 71 & 18 & 1 & 0 & 250 & 2.78 & 2 \\
\hline 23. & $\begin{array}{l}\text { Way of using insecticides/pesticides and aqua- } \\
\text { drugs }\end{array}$ & 63 & 21 & 6 & 0 & 237 & 2.63 & 6 \\
\hline \multicolumn{9}{|c|}{ F. Harvesting, fish preservation and marketing of product } \\
\hline 24. & Time of harvesting & 27 & 28 & 24 & 11 & 161 & 1.79 & 21 \\
\hline 25. & Methods of harvesting & 31 & 21 & 23 & 15 & 158 & 1.76 & 23 \\
\hline 26. & Time of preservation & 43 & 24 & 16 & 7 & 193 & 2.14 & 13 \\
\hline 27. & Techniques of preservation & 56 & 22 & 7 & 5 & 219 & 2.43 & 9 \\
\hline 28. & Techniques of egg collection & 8 & 20 & 19 & 43 & 83 & 0.92 & 27 \\
\hline 29. & Ways of early marketing system & 55 & 14 & 11 & 10 & 204 & 2.27 & 11 \\
\hline
\end{tabular}

Notes: $\mathrm{H}=$ High (score: 3 ), $\mathrm{M}=$ medium (score: 2), $\mathrm{L}=$ Low (score: 1 ), $\mathrm{N}=$ Not at all (score: 0 ), $\mathrm{TS}=$ Total score, $\mathrm{M}=$ Mean, $\mathrm{P}=$ Priority 


\section{Selected characteristics of the fish farmers}

The distribution of the fish farmers according to their selected characteristics have been shown in the Table 3. Data contained in Table 3 reveal that 67.84 per cent of the fish farmers were middle to old age category. More than half (53.3 per cent) of the respondents had secondary education. Majority of the respondents (70 per cent) had small to medium household size. About 99 per cent of the respondents had medium to large farm size. The entire fish farmer had medium to high annual income. The organizational participation of the respondents (100 per cent) was low; however, more than half of them had medium communication exposure (67.8 per cent) and social mobility (55.6 per cent). About 99 per cent of the fish farmers had medium knowledge as 38.9 per cent had short training experience.

Table 3. Salient features of the selected characteristics of the respondents

\begin{tabular}{|c|c|c|c|c|c|c|c|}
\hline \multirow{2}{*}{$\begin{array}{c}\text { Characteristics } \\
\text { (Measurement } \\
\text { units) }\end{array}$} & \multirow{2}{*}{$\begin{array}{l}\text { Scoring } \\
\text { system }\end{array}$} & \multicolumn{2}{|c|}{ Range } & \multicolumn{2}{|l|}{ Respondents } & \multirow[b]{2}{*}{ Mean } & \multirow[t]{2}{*}{ SD } \\
\hline & & Possible & Observed & Category & $\begin{array}{c}\text { Per cent } \\
(\mathrm{n}=90)\end{array}$ & & \\
\hline Age & Actual year & Unknown & $19-61$ & $\begin{array}{c}\text { Young (up to 35) } \\
\text { Middle aged (36-45) } \\
\text { Old }(>45)\end{array}$ & $\begin{array}{l}32.2 \\
34.4 \\
33.4\end{array}$ & 41.24 & 8.96 \\
\hline Years of schooling & $\begin{array}{l}\text { Years of } \\
\text { schooling }\end{array}$ & Unknown & $0-18$ & $\begin{array}{c}\text { Illiterate }(0) \\
\text { Primary }(1-5) \\
\text { Secondary }(6-10) \\
\text { Higher secondary }(>10)\end{array}$ & $\begin{array}{c}1.1 \\
16.7 \\
53.3 \\
28.9\end{array}$ & 8.91 & 3.80 \\
\hline Household size & $\begin{array}{c}\text { No. of } \\
\text { members }\end{array}$ & Unknown & $2-13$ & $\begin{array}{l}\text { Small (up to } 4 \text { ) } \\
\text { Medium (5-7) } \\
\text { Larger }(>7)\end{array}$ & $\begin{array}{c}16.7 \\
53.3 \\
30\end{array}$ & 6.69 & 2.40 \\
\hline Farm size & Hectares & Unknown & $0.18-2.92$ & $\begin{array}{c}\text { Marginal }(.021-0.2) \\
\text { Small }(>0.2-1.0) \\
\text { Medium }(>1.0-3.0)\end{array}$ & $\begin{array}{c}1.1 \\
54.5 \\
44.4\end{array}$ & 0.97 & 0.46 \\
\hline Annual income & Tk. '000' & Unknown & $75-520$ & $\begin{array}{l}\text { Low (up to 60) } \\
\text { Medium }(61-150) \\
\text { High }(>150)\end{array}$ & $\begin{array}{c}0 \\
21.1 \\
78.9\end{array}$ & 213.6 & 82.33 \\
\hline $\begin{array}{l}\text { Organizational } \\
\text { participation }\end{array}$ & Scale score & $0-21$ & $0-5$ & $\begin{array}{c}\text { Low (up to } 7 \text { ) } \\
\text { Moderate (8-21) }\end{array}$ & $\begin{array}{c}100 \\
0\end{array}$ & 1.73 & 1.05 \\
\hline $\begin{array}{l}\text { Communication } \\
\text { exposure }\end{array}$ & Scale score & $0-42$ & $0-36$ & $\begin{array}{l}\text { Low (up to 14) } \\
\text { Medium }(15-29) \\
\text { High }(>29)\end{array}$ & $\begin{array}{l}14.4 \\
67.8 \\
17.8\end{array}$ & 22.40 & 8.63 \\
\hline Social mobility & Scale score & $0-12$ & $0-12$ & $\begin{array}{l}\text { Low (up to } 4) \\
\text { Medium (5-9) } \\
\text { High (>9) }\end{array}$ & $\begin{array}{c}35.6 \\
55.6 \\
8.9\end{array}$ & 5.39 & 3.04 \\
\hline Credit received & Tk. '000' & Unknown & $0-100$ & $\begin{array}{l}\text { No credit }(0) \\
\text { Small (up to } 30) \\
\text { Medium }(31-60) \\
\text { High }(>60)\end{array}$ & $\begin{array}{c}20 \\
43.3 \\
28.9 \\
7.8\end{array}$ & 29.51 & 23.30 \\
\hline Training received & No. of days & Unknown & $0-120$ & $\begin{array}{l}\text { Short-term (up to7) } \\
\text { Mid-term (8-15) } \\
\text { Long-term (>15) }\end{array}$ & $\begin{array}{c}38.9 \\
21.1 \\
40\end{array}$ & 14.32 & 15.99 \\
\hline Knowledge on IFF & Scale score & $0-20$ & $8.50-17.50$ & $\begin{array}{l}\text { Low (up to } 7) \\
\text { Medium }(8-15) \\
\text { High }(>15)\end{array}$ & $\begin{array}{c}0 \\
98.9 \\
1.1\end{array}$ & 11.31 & 1.76 \\
\hline
\end{tabular}




\section{Relationship between the selected characteristics of the fish farmers and their extent of training needs on integrated fish farming}

The purpose of this section is to determine the relationships between the selected characteristics of the fish farmers and their extent of training needs on integrated fish farming. The characteristics included age, years of schooling, household size, farm size, annual income, organizational participation, communication exposures, social mobility, credit received, and knowledge with IFF. Each of the characteristics was considered as an independent variable, while the extent of training needs of the integrated fish farmers on integrated fish farming was the only dependent variable in this study. The summary of the results of the correlation analysis between the selected characteristics of the respondents and their extent of training needs on integrated fish farming has been shown in the Table 4. Findings reveal that out of the ten selected characteristics of the respondent years of schooling, organizational participation, communication exposure, social mobility and knowledge on IFF showed positive significant relationship. On the other hand, age, household size, farm size, annual income, and credit received had no relationships with the extent of training needs.

Table 4. Relationship between the dependent and independent variables

\begin{tabular}{l|lc}
\hline Dependent variable & \multicolumn{1}{|c}{ Independent variables } & Coefficient of correlation $(\mathrm{r})$ values with $88 \mathrm{df}$ \\
\hline & Age & -0.130 \\
& Years of schooling & $0.895^{* *}$ \\
& Household size & -0.012 \\
& Farm size & 0.129 \\
& Annual income & -0.089 \\
Training needs of the & Organizational & $0.405^{* *}$ \\
& participation & $0.282^{* *}$ \\
& Communication exposure & $0.333^{* *}$ \\
& Social mobility & 0.199 \\
& Credit received & $0.425^{* *}$ \\
\hline
\end{tabular}

** Significant at 0.01 level of probability; * Significant at 0.05 level of probability

Education broadens outlook of the people and leads them to explore new ideas to solve problems. Years of schooling of the respondents could play a significant role of extent of training needs on integrated fish farming. Integrated fish farmers were affiliated with different organizations like school committee, mosque committee, madrasha committee, bazar committee etc. They become more aware about their training needs. Organizational participation of the respondents could play a significant role with their extent of training needs on integrated fish farming. Communication exposure changes their attitude towards the adoption of improved farming practices. In this study area, where the fish farmers easily communicate with District Fisheries Office, Upazila Headquarters, Upazila Fisheries Office, BAU and BFRI. These institutions are very near the study area. The fish farmers are likely to 
gain more knowledge and skills about integrated fish farming from those institutions. Social mobility of the respondents could play a significant role of extent of training needs on integrated fish farming. The more learning and more experiences on integrated fish farming might lead them to identify their training needs on fish farming. Knowledge on integrated fish farming of the respondents could play a significant role with their extent of training needs on integrated fish farming.

\section{CONCLUSIONS}

The findings clearly indicated that more than half (56.7 per cent) of the respondents had high training needs on integrated fish farming. They have medium knowledge about integrated fish farming. By this reason, they were not improving their farming systems. Thus, the respondents logically felt high training needs on their integrated fish farming. The findings indicated that 53.3 per cent had secondary level of education and was positively correlated with their extent of training needs on integrated fish farming. Half of the fish farmers were educated, educated person more aggressive and innovative. Almost all of the fish farmers (100 per cent) had low organizational participation which was significantly related with their extent of training needs on integrated fish farming. The findings indicate that the fish farmers were affiliated with different organizations which deal with microcredit programs. Through their participation, they become more aware of their training needs. The findings indicated that (67.8 per cent) had medium communication exposure and (55.6) per cent had medium social mobility. Communication exposure and social mobility of the fish farmers had significant relationship with their extent of training needs on integrated fish farming. It is assumed that communication exposure and social mobility of the fish farmers changes their attitude towards the adoption of improved farming practices. Almost all the respondents (98.9 per cent) had medium knowledge on integrated fish farming and knowledge on integrated fish farming of the fish farmers had significant relationship with their extent of training needs on IFF. The level of education of the fish farmers is comparatively better and this might create a better setting for learning integrated fish farming techniques. Thus, the significant variables should be given more importance to identify the training needs of the fish farmers as well as formulating relevant programmes to meet the respondents' training needs.

\section{REFERENCES}

Ahmed, N. 2007. Need Assessment for Capacity Building of Women for Practicing Post Harvest Activities of Vegetables. M.S. Thesis. Department of Agricultural Extension Education, Bangladesh Agricultural University, Mymensingh, Bangladesh.

AIT. 1994. Partners in Development: The Promotion of Sustainable Aquaculture. Bangkok: Asian Institute of Technology.

DoF. 2011. Fishery Statistical Yearbook of Bangladesh 2009-2010. 46 Matshya Bhaban, Dhaka: Fisheries Resources Survey System, Department of Fisheries (DoF), Ministry of Fisheries and Livestock (MoFL). 
Edwards, P., Demaine, H., Innes-taylor, N. and Turongrung, D. 1996. Sustainable Aquaculture for Small Scale Farmers: Need for a Balanced Model. Outlook on Agriculture, 25(1): 19-26.

FAO. 1977. China: Recycling of Organic Wastes in Agriculture. FAO Soils. Bull., 40 pp.

Ferdousi, Z. 2010. Need for Capacity Strengthening of Women Members of BAUEC for Homestead Gardening. M.S. Thesis. Department of Agricultural Extension Education, Bangladesh Agricultural University, Mymensingh, Bangladesh.

Kausar, R. M. 2009. Fisheries Knowledge of Pond Owners in Two Villages of Mymensingh District. M.S. Thesis. Department of Agricultural Extension Education, Bangladesh Agricultural University, Mymensingh, Bangladesh.

Lightfoot, C., Cruz, C. R. D. and Carangal, V. R. 1990. International Research Collaboration in RiceFish Research. NAGA, The ICLARM Quarterly, 13 (4), 12-13.

Little, D. C. and Edwards, P. 1999. Alternative Strategies for Livestock-fish Integration with Emphasis on Asia. Ambio, 28, 118-124.

Little, D. C. and Edwards, P. 2003. Integrated Livestock-fish Farming Systems. 189 Rome: Food and Agriculture Organization of the United Nations.

Little, D. C. and Muir, J. 2003. Integrated Agri-aquauculture Systems-The Asian Experience. In: Gooley, G.J. and Gavine, F.M., (Eds.) Integrated Agri-Aquaculture Systems. A Resource Handbook for Australian Industry Development. A Report for the Rural Industries Research and Development Corporation. RIRDC Project no.MFR-2A, pp. 24-36. Victoria, Australia, RIRDC.

Lo, C. P. 1996. Environmental Impact on the Development of Agricultural Technology in China: case of the Dike-pond ('Jitang') System of Integrated Agriculture-aquaculture in the Zhujiang Delta of China. Agriculture Ecosystems \& Environment, 60, 183-195.

Meenanbigai, J. and Seetharamen, R. K. 2003. Training Needs of Extension Personnel in Communication and Transfer of Technology. Agriculture Newsletter, No.48:19.

Nuruzzaman, M. 1991. Duck-cum-Fish Integrated Farming System in Bangladesh. Bangladesh Fisheries Research Institute, Mymensingh, Bangladesh.

Pearce, F. 2006. The Pearched Planet. In: Weeb, J., (Ed.) New Scientist, pp. 32-36. England: Reed Business Information Ltd.

Ruddle, K. and Zhong, G. F. 1988. Integrated Agriculture-aquaculture in South China. The Dikepond System of the Zhujiang Delta . Cambridge University Press, Cambridge, 173 p.

Wahab, M. A., Rahmatullah, S. M., Beveridge, M. C. M., Baird, D. J. and Tollervey, A. G. 1997. Impact of Sharpunti (Puntius gonionotus) in the Polyculture of Native Major Carps and Mitigation Measures Using Duckweed (Lemna sp.). In: Anonymous Proceedings of the Fourth Asian Fisheries Forum held on 16-20 October, 1995, Beijing, China. 